\title{
INTRODUCTION OF FORMATIVE ASSESSMENT: AN ESSENTIAL COMPONENT OF CBME
}

Sharma $\mathrm{M}^{* 1}$,Bajaj JK ${ }^{2}$, Kaur K ${ }^{3}$, Arora R ${ }^{4}$.

${ }^{* 1}$ Professor. Department of Anatomy, PIMS, Jalandhar, Punjab, India.

${ }^{2}$ Professor \& Head, Department of Pharmacology PIMS, Jalandhar, Punjab, India.

${ }^{3}$ Director- Principal, PIMS, Jalandhar, Punjab, India.

${ }^{4}$ Professor \& Head, Department of Physiology PIMS, Jalandhar, Punjab, India.

\section{ABSTRACT}

Background: The Medical Council of India has visualized the effective outcome based strategy of Competency Based Medical Education where the assessment is the essential component of competencies. Formative assessment is a systematic approach designed for students during a particular period of study to provide motivation for learning. It helps the student to set the desired but attainable goals and to follow the steps required to achieve those specified goals.

Aim: To introduce the feedback to the students during substages and after the theory tests and to assess students and teacher's perspective towards feedback.

Material and Method: The project was done in the Department of Anatomy, Punjab Institute of Medical Sciences, Jalandhar involving $1^{\text {st }}$ year batch students and faculty members of Anatomy.

Results: A good percentage of students were satisfied with the formative assessment and wanted the process to be continued in the subsequent years too. All the faculty members had positive response for formative assessment.

Conclusion: Formative assessment is the strategy to encourage the students for self directed learning and self assessment.

KEY WORDS: Formative assessment, Feedback, Self directed learning.

Address for Correspondence: Dr. Sharma M, Professor. Department of Anatomy, PIMS, Jalandhar, Punjab, India. E-Mail: psmamta1997@gmail.com

Access this Article online

Quick Response code

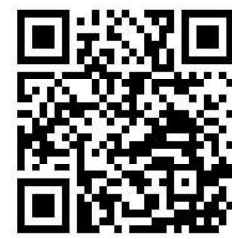

DOI: $10.16965 /$ ijar.2019.242



\section{INTRODUCTION}

The fundamental principles for any educational endeavor are-Objectives, teaching -learning method and assessments[1].Assessment in education is the product of the 20 th century. It is "a systematic process for gathering data about student achievement," which is an essential component of teaching[2].

Competency Based Medical Education (CBME) requires assessment processes that are more continuous and frequent, criterion-based and developmental[3]. It focuses on accountability and curricular outcomes and is organized around competencies, promotes greater learnercentredness and de-emphasizes time-based curricular design[4].

There are two broad categories, termed summative and formative. The summative assessments have a strong societal flavor which occur at a defined points during a course, 
usually at the middle and at the end and these are primarily assessments of learning[1].

Michael Scriven proposes the use of "formative and summative" assessment in order to make the distinction between the roles of evaluation. "Hence, assessment is perceived to serve two different purposes: 1) informative, to improve instruction, and, 2) summative to measure students' achievement "[5].

Though, in the literature, it remained a mystery but still a continuous emphasis is given on the use of formative assessment over the last number of years[6,7]. It is considered as an expected assistance to ensure that students are able to path their growth and reach specified goals.

With the assessment of their knowledge, it also helps them to learn by encouraging positive faith and self-confidence. So, the provision of opportunities for formative assessment has been recognized as a significant benefit, which has impact on students result than any other teaching strategy $[6,8,9,10]$.

The formative assessment not only identify intellectual capabilities of students for improved achievement, but also determine their strengths and weaknesses which helps in modifying teaching learning methods if needed [11]. It has been recognized that retention of gained knowledge is improved when educational encounters are properly spaced and repeated over a defined period and students are encouraged to apply ongoing learning and not a cramming skills just before the final examinations $[12,13]$.

Feedback is the essential component of formative assessment for which expertise is required by teachers and students for providing and receiving feedback respectively[14].

The formative assessments are systematically designed interventions to enhance emotional and motivational support for learning and achievement by students. The Internal motivation is reinforced by having clear standards of performance accompanied with feedback and the regular review of the that feedback by the trained advisors help students in identifying their gap in acquired and expected knowledge and by enlightening students with what will be expected on summative assessments. So, by providing feedback on their thinking, and by guiding the direction of their learning, the students are allowed to track their progress of learning which will help in implementing appropriate learning plan $[9,15,16,17]$. These are better called assessment for learning or learning oriented assessments[18].

Formative assessment is the most effective educational practice when it comes to improve academic excellence [19]. A clear and shared vocabulary and finally a sound research validated framework for best practices informative assessment and formative evaluation are certain conditions which must be entrenched to use assessment productively so that maximum student success can be achieved [20].

For the opportunity of formative assessment to be maximized, it must therefore feature as a built-in component of a planned curriculum[15]. Once the learning period is over, the progress of knowledge is essential for enabling the graduates to use and rely on that knowledge in their chosen career [21].

\section{MATERIALS AND METHODS}

The project was done in the Department of Anatomy, Punjab Institute of Medical Sciences, Jalandhar involving $1^{\text {st }}$ year batch students and faculty members of Anatomy. The approval for the project was taken from institutional ethics committee. The sensitization of students and faculty was done on formative assessment. The feedback questionnaires for students and faculty were developed .Student's questionnaire was validated by the students of senior batch and faculty questionnaire was validated by MEU members and approved by institutional ethics committee.

After sensitization of faculty and students regarding the significance of formative assessment and the approval of project from Institutional Ethics Committee, a class of 150 students of $1^{\text {st }}$ year was divided into 6 batches. One faculty member was assigned to each batch. At the time of substage, the given topic was discussed with the students simultaneously with their assessment. Their doubts were cleared during feedback session. In the same way theory papers were distributed to all assigned faculty members. After marking the papers, 
these were discussed in assigned batches in detail for the contents of paper, attempt of questions and requirements of each question. The perceptions and preferences of students and teachers were recorded on self structured, prevalidated questionnaires using 5 point Likert scale. Open ended questions were analysed descriptively. The student feedback questionnaire (Annexure 1) consisted of 11 questions on 5-point Likert scale Agree, Strongly Agree, Neutral, Disagree, Strongly disagree and two open ended questions. Faculty feedback questionnaire (Annexure 2) consisted of 7 questions on 5-point Likert scale (1-Agree, 2- Strongly Agree, 3-Neutral, 4- Disagree, 5-Strongly Disagree) and one open ended question.

\section{OBSERVATIONS AND RESULTS}

All the 150 students of $1^{\text {st }}$ year MBBS participated in the project.

Table 1: Showing Student's

\begin{tabular}{|c|c|c|c|c|c|c|}
\hline S.NO & & $\begin{array}{c}1 \\
\text { AGREE } \\
N(\%)\end{array}$ & $\begin{array}{c}2 \\
\text { STRONGLY } \\
\text { AGREE } \\
N(\%)\end{array}$ & $\begin{array}{c}3 \\
\text { NEUTRAL } \\
\text { N }(\%)\end{array}$ & $\begin{array}{c}4 \\
\text { DISAGREE } \\
N(\%)\end{array}$ & $\begin{array}{c}5 \\
\text { STRONGLY } \\
\text { DISAGREE } \\
N(\%)\end{array}$ \\
\hline 1. & Received one to one feedback & $\begin{array}{c}84 \\
(56 \%)\end{array}$ & $\begin{array}{c}24 \\
(16 \%)\end{array}$ & $\begin{array}{c}34 \\
(22.6 \%)\end{array}$ & $\begin{array}{c}7 \\
(4.6 \%)\end{array}$ & $\begin{array}{c}1 \\
(0.6 \%)\end{array}$ \\
\hline 2. & $\begin{array}{l}\text { Teachers made full efforts to } \\
\text { explain the contents of topic }\end{array}$ & $\begin{array}{c}68 \\
(45.3 \%) \\
\end{array}$ & $\begin{array}{c}58 \\
(38.6 \%) \\
\end{array}$ & $\begin{array}{c}22 \\
(14.6 \%)\end{array}$ & $\begin{array}{c}2 \\
(1.3 \%)\end{array}$ & 0 \\
\hline 3. & $\begin{array}{l}\text { My doubts are cleared during } \\
\text { feedback session }\end{array}$ & $\begin{array}{c}85 \\
(56.6 \%)\end{array}$ & $\begin{array}{c}36 \\
(24 \%)\end{array}$ & $\begin{array}{c}24 \\
(16 \%)\end{array}$ & $\begin{array}{c}3 \\
(2 \%)\end{array}$ & $\begin{array}{c}2 \\
(1.3 \%)\end{array}$ \\
\hline 4. & $\begin{array}{l}\text { Feedback process supported my } \\
\text { learning process }\end{array}$ & $\begin{array}{c}96 \\
(64 \%)\end{array}$ & $\begin{array}{c}40 \\
(26.6 \%)\end{array}$ & $\begin{array}{c}11 \\
(7.3 \%)\end{array}$ & $\begin{array}{c}3 \\
(2 \%)\end{array}$ & 0 \\
\hline 5. & $\begin{array}{l}\text { Created a positive working and } \\
\text { learning atmosphere }\end{array}$ & $\begin{array}{c}77 \\
(51.3 \%)\end{array}$ & $\begin{array}{c}41 \\
(27.3 \%) \\
\end{array}$ & $\begin{array}{c}23 \\
(15.3 \%)\end{array}$ & $\begin{array}{c}5 \\
(3.3 \%)\end{array}$ & $\begin{array}{c}4 \\
(2.6 \%)\end{array}$ \\
\hline 6. & $\begin{array}{l}\text { Encouraged me to participate } \\
\text { actively during substages and } \\
\text { stages }\end{array}$ & $\begin{array}{c}61 \\
(40.6 \%)\end{array}$ & $\begin{array}{c}49 \\
(32.6 \%)\end{array}$ & $\begin{array}{c}28 \\
(18.6 \%)\end{array}$ & $\begin{array}{c}7 \\
(4.6 \%)\end{array}$ & $\begin{array}{c}5 \\
(3.3 \%)\end{array}$ \\
\hline 7. & $\begin{array}{l}\begin{array}{l}\text { Encouraged me to work } \\
\text { independently }\end{array} \\
\end{array}$ & $\begin{array}{c}73 \\
(48.6 \%)\end{array}$ & $\begin{array}{c}37 \\
(24.6 \%)\end{array}$ & $\begin{array}{c}34 \\
(22.6 \%) \\
\end{array}$ & $\begin{array}{c}4 \\
(2.6 \%) \\
\end{array}$ & $\begin{array}{c}2 \\
(1.3 \%)\end{array}$ \\
\hline 8. & $\begin{array}{l}\text { Helped me in realizing my } \\
\text { strengths and weaknesses }\end{array}$ & $\begin{array}{c}63 \\
(42 \%)\end{array}$ & $\begin{array}{c}44 \\
(29.3 \%) \\
\end{array}$ & $\begin{array}{c}37 \\
(24.6 \%) \\
\end{array}$ & $\begin{array}{c}6 \\
(4 \%)\end{array}$ & 0 \\
\hline 9. &  & $\begin{array}{c}72 \\
(48 \%)\end{array}$ & $\begin{array}{c}30 \\
(20 \%)\end{array}$ & $\begin{array}{c}35 \\
(23.3 \%)\end{array}$ & $\begin{array}{c}12 \\
(8 \%)\end{array}$ & $\begin{array}{c}1 \\
(0.6 \%)\end{array}$ \\
\hline 10. & $\begin{array}{l}\text { Altogether ,I was satisfied with } \\
\text { the formative assessment }\end{array}$ & $\begin{array}{c}87 \\
(58 \%)\end{array}$ & $\begin{array}{c}42 \\
(28 \%)\end{array}$ & $\begin{array}{c}15 \\
(10 \%)\end{array}$ & $\begin{array}{c}5 \\
(3.3 \%) \\
\end{array}$ & $\begin{array}{c}1 \\
(0.6 \%)\end{array}$ \\
\hline 11. & $\begin{array}{l}\text { I feel that process of feedback } \\
\text { should be continued in the } \\
\text { subsequent yearstoo }\end{array}$ & $\begin{array}{c}60 \\
(\mathbf{4 0} \%)\end{array}$ & $\begin{array}{c}68 \\
(45.3 \%)\end{array}$ & $\begin{array}{c}17 \\
(11.3 \%)\end{array}$ & $\begin{array}{c}5 \\
(3.3 \%)\end{array}$ & - \\
\hline
\end{tabular}

$72 \%$ of the students responded that they had received one to one feedback which was quite effective (Graph 1).

Graph 1: Perception of students regarding process of Formative Assessment.

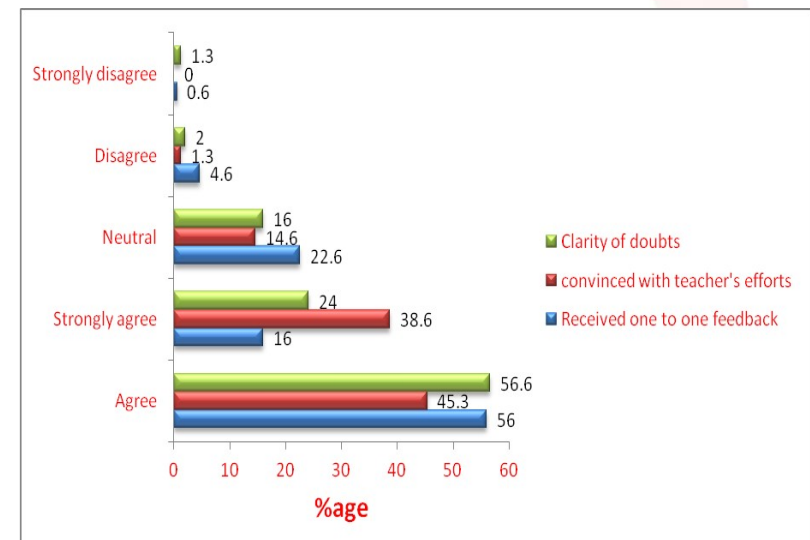

$78.6 \%$ were agreed that formative assessment gave them a positive working and learning atmosphere thereby encouraging them (73.2\%) to participate actively and independently. $90.6 \%$

admitted that formative assessment supported in learning process(Graph 2). 86\% students were satisfied with the formative assessment (Graph 3) and around $85.3 \%$ of students feel that formative assessment should be introduced in the subsequent years too (Graph 4).

Graph 2: Formative assessment helps in learning.




Graph 3: Students satisfied with the formative assessment.

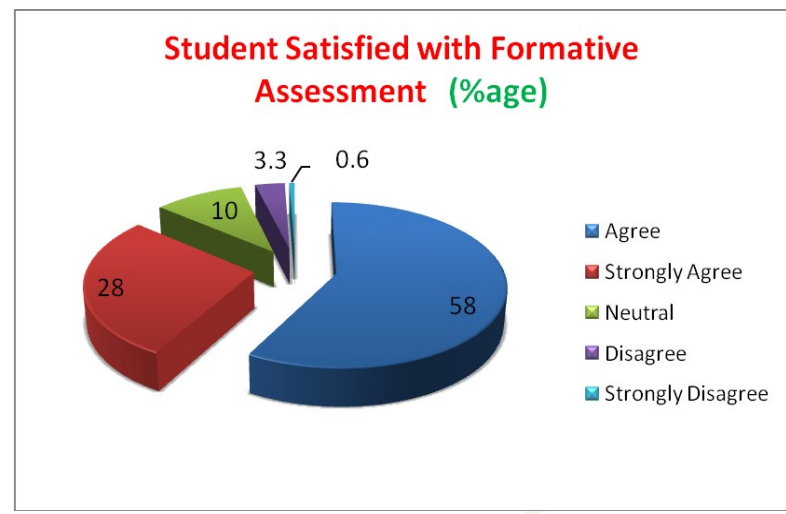

Graph 4: Students opinion regarding feedback process.

Feedback Process Should Continue (\%age)

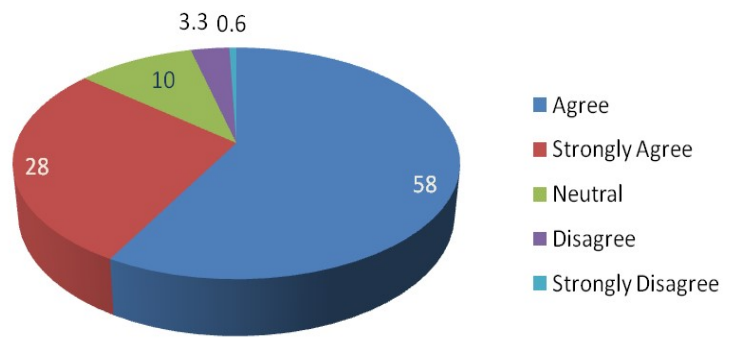

Salient points of the feedback received from students for Open ended questions were:

1. More time should be given to each student during feedback session.

2. Syllabus for formative assessment should be less.

3. Assignment sheets should be returned to students for improvement in future performance.

4. Formative assessment should be continued in subsequent years too.

B. Teacher's Perception of Formative Assessment. Table 2: Showing Teacher's perception of Formative Assessment.

\begin{tabular}{|c|l|c|c|c|c|c|}
\hline S.No & Questions & Agree & $\begin{array}{l}\text { Strongly } \\
\text { agree }\end{array}$ & Neutral & Disagree & $\begin{array}{c}\text { Strongly } \\
\text { disagree }\end{array}$ \\
\hline 1 & $\begin{array}{l}\text { My students have shown a } \\
\text { greater interest in learning } \\
\text { the subject }\end{array}$ & $\begin{array}{c}1 \\
(16.7 \%)\end{array}$ & $\begin{array}{c}5 \\
(83.3 \%)\end{array}$ & - & - & - \\
\hline 2 & $\begin{array}{l}\text { My relationship with the } \\
\text { students has improved }\end{array}$ & $\begin{array}{c}4 \\
(66.7 \%)\end{array}$ & $\begin{array}{c}2 \\
(33.3 \%)\end{array}$ & - & - & - \\
\hline 3 & $\begin{array}{l}\text { My students dare to ask } \\
\text { more questions during } \\
\text { substages }\end{array}$ & $\begin{array}{c}3 \\
(50 \%)\end{array}$ & $\begin{array}{c}1 \\
(16.7 \%)\end{array}$ & - & 2 & - \\
\hline 4 & $\begin{array}{l}\text { I pay more attention to } \\
\text { individual needs }\end{array}$ & $\begin{array}{c}3 \\
(50 \%)\end{array}$ & $\begin{array}{c}3 \\
(50 \%)\end{array}$ & - & - & - \\
\hline 5 & $\begin{array}{l}\text { I discuss the strengths and } \\
\text { weaknesses of my students }\end{array}$ & $\begin{array}{c}4 \\
(66.7 \%)\end{array}$ & $\begin{array}{c}2 \\
(33.3 \%)\end{array}$ & - & - & - \\
\hline 6 & $\begin{array}{l}\text { I liked the concept of } \\
\text { formative assessment }\end{array}$ & $\begin{array}{c}2 \\
(33.3 \%)\end{array}$ & $\begin{array}{c}4 \\
(66.7 \%)\end{array}$ & - & - & - \\
\hline 7 & $\begin{array}{l}\text { It should be done for whole } \\
\text { session }\end{array}$ & $\begin{array}{c}1 \\
(16.7 \%)\end{array}$ & $\begin{array}{c}5 \\
(83.3 \%)\end{array}$ & - & - & - \\
\hline
\end{tabular}

All the faculty members had positive response for formative assessment. They perceived that individual needs of students were given attention which motivated them to discuss their strengths and weaknesses. (Graph 5)S

Graph 5: Showing Perceptions of teachers.

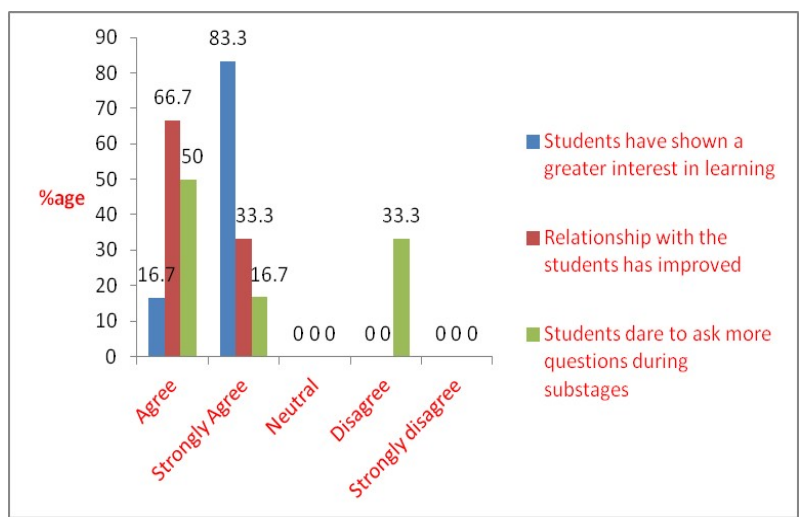

The concept of formative assessment was affirmed as productive and informative by all the faculty members. They also suggested its continuity in subsequent batches too.

Salient points of the feedback received from teachers for open ended questions were:

1.All the faculty members agreed that formative assessment was good for both teachers and students and it is quite informative and productive type of assessment. But it should be accompanied with proper planning of syllabus and adequate spacing of revision tests or substages.

2.The format of theory question paper should also be discussed with the students prior to final stages or exams.

\section{DISCUSSION}

The appropriate assessment methods help students to understand the focal points of the course and curriculum which improves their confidence level, enthusiasm and creativity in learning [20]. This target of deeper learning is usually achieved when knowledge is not restricted to learning a collection of isolated facts, and is instead a result of an active learning process being engaged and knowledge being fully understood and retained in context by the learner [22]. Previous study analysed that medical students prefer individual feedback which is very effective [23].

$71.3 \%$ of students came to know about their strengths and weaknesses of the concerned topics. McMillan and Hearn also noticed that formative assessment encourages the students for self-assessment which is a process in which 
they monitor and evaluate the nature of their thinking required to improve their understanding [24]. Bruce and Chappuis considered self-reflection and goal setting as key aspects of self-assessment. With time and training, students will become more responsible for evaluating how close they are to the learning target, identifying what they need to improve, and selecting learning strategies to achieve the same $[25,26]$.

A good percentage of students (86\%) were satisfied with the formative assessment and wanted the process to be continued in the subsequent years too. Many studies support this evidence, where students want and value quality feedback that is identified as an important indicator of effective teaching $[27,28,29]$. Formative assessment will escalate the progress of students if they will be able to use this opportunities efficaciously and realize the need to develop their learning skills[30].

All the faculty members(100\%) agreed that teacher-student relationship has been improved with formative assessment. Bloom's Theory of Mastery Learning also stated that student learning goals are promoted by formative assessment that helps in developing the perfect teacher-student relationship which is necessary for successful teaching and learning process [31]. Previous study described that corrective or reinforcing feedback, is an essential part of medical education, which helps to promote learning and ensures that standards are met [32].

The students must be motivated to use their knowledge to analyze, compare and evaluate what they have learned rather than simply rote memorization. This type of fortified learning helps to provide base for alternative types of assessment in order to measure academic benefits [33]. Providing students with a foundation of constructivism in the classroom may help support this type of teaching and learning process [34]. All the faculty members liked the concept of formative assessment and were in favour of the incorporation of process for future batches.

\section{CONCLUSION}

Formative assessment is the strategy to encour- age the students for self directed learning and self assessment which helps them to understand the requirement of task to meet the well defined learning objective which is very much required for them to be a competent professional. In India, as the medical education is moving towards competency - based education from 2019 onwards, formative assessment is to be approached systematically and attention should be given to curriculum content, timing and learning through assessment.

\section{ACKNOWLEDGEMENTS}

I acknowledge the sincere efforts put in by faculty members of Anatomy department and medical education unit of PIMS for giving their valuable suggestions. I am also thankful to 1st year MBBS students for their participation and suggestions.

\section{Conflicts of Interests: None}

\section{REFERENCES}

[1]. Kulasegaram K, Rangachari PK. Beyond formative assessments to enrich student learning. Adv Physiol Educ. 2018;42: 5-14.

[2]. Dhindsa, H., Omar, K., \& Waldrip, B. Upper Secondary Bruneian Science Students' Perceptions of Assessment. International Journal of Science Education 2007 August1;29(10):1281-1280.

[3]. Holmboe ES, Sherbino J, Long DM et al.The role of assessment in competency-based medical education. Medical Teacher 2010;32:676-682.

[4]. Frank JR, Snell LS, Cate OT, et al.Competency-based medical education: theory to practice. Medical Teacher 2010;32(8):638-645.

[5]. Scriven, M. The methodology of evaluation (Vol. 1). Washington, DC: American Educational Research Association;1967.

[6]. Black P, Wiliam D. Assessment and classroom learning. Assess Educ. 1998; 5:7-74.

[7]. Leung C, Mohan B.Teacher formative assessment and talk in classroom contexts: Assessment as discourse and assessment of discourse. Language $T$ esting 2004; 21(3):335-359.

[8]. Bierer SB, Dannefer EF, Taylor C, Hall P, Hull AL. Methods to assess students' acquisition, application and integration of basic science knowledge in an innovative competency-based curriculum. Med Teach. 2008; 30:e171-e177.

[9]. Rolfe I, McPherson J. Formative assessment: how am I doing? Lancet 1995;345:837-839.

[10]. Carrillo-de-la-Pena MT, Bailles E, Caseras X, Martinez ,Ortet $G$ et al. Formative assessment and academic achievement in pre-graduate students of health sciences. Adv Health Sci Educ TheoryPract. 2009;14: 61-67.

[11]. Mennin,S.P , Kalishman,S. Student assessment. Academic Medicine. 1998;73(9):S 46-S 54. 
[12]. Krasne S, Wimmers PF, Relan A, Drake TA. Differential effects of two types of formative assessment in predicting performance of first year medical students. Adv Health Sci EducTheory Pract.2006; 11:155-171.

[13]. Kerfoot BP, Baker HE, Koch MO, Connelly D, Joseph DB et al. Randomize, controlled trial of spaced education to urology resident in the United states and Canada. Urol.2007;177:1481-1487.

[14]. Hattie J,Jaeger R . Assessment and classroom learning: A deductive approach. Assessment in Education.1998;5(1):111-122.

[15]. Rushton A. Formative assessment: a key to deep learning? Med Teach. 2005; 27: 509-513.

[16]. Sadler,D. Formative assessment and the design of instructional systems. Instructional Science.1989;18:119-144.

[17]. Wass V, Vleuten C ,Van der, Shatzer J , Jones R. Assessment of clinical competence. The Lancet 2001;357(9260): 945-949.

[18]. Carless D. Learning-oriented assessment: conceptual bases and practical Implications. Innov Educ Teach Int 2007;44:57-66.

[19]. Kumar AT, Sangeeta A,Rashmi R,Anbu N,Aravazhi et al. Int J Contemp Pediatr.2018 Mar;5(2):621-628.

[20]. Stiggins RJ. From the formative assessment to assessment for learning. A path to success In standard based schools. Phi Delta Kappan .2005;87(4):324-329.

[21]. Sugand K, Abrahams P, Khurana A. The anatomy of anatomy: a review for it modernization. Anat Sci Educ.2010;3:83-93.

[22]. Harlen W and James M. Assessment and learning: differences and relationships between formative and summative assessment .Assess Educ.1997; 4:365-379.

[23]. Parikh A, McReelis K and Hodges B. Student feedback in problem based learning : A survey of 103 final year students across five Ontario medical schools. Medical Education 2001;35:632-636.
[24]. McMillan, J. H, J. Hearn. Student self-assessment: The key to stronger student motivation and higher achievement. Educational Horizons 2008;87(1):4049.

[25]. Bruce, L. B. Student self-assessment: Making standards come alive. Classroom Leadership 2001; 5 (1): 1-6.

[26]. Chappuis, J. Helping students understand assessment. Educational Leadership 2005; 63 (3):39-43.

[27]. Hyland P. Learning from feedback on assessment in: The practice of University history teaching, eds. Hyland $P$ and Booth A: Manchester University Press:2000.

[28]. O' Donovan B, Prince M andRust C. Know what I mean? Enhancing student understanding of assessment standards and criteria. Teaching in Higher education 2004; 9:325-335.

[29]. Ramsden P. Learning to teach in higher education. $2^{\text {nd }}$ reved. London: Routledge: 2003.

[30]. Evans DJR, Zeun P, Stanier RA .Motivating student learning using a formative assessment journey. J Anat.2014 Mar; 224(3):296-303.

[31]. Bloom, B. S. Learning for mastery; 1968

[32]. Ende J. Feedback in clinical medical education .JAMA1983; 250:777-778.

[33]. Stiggins, R, Chappuis, J. What a difference a word makes. Journal of Staff Development 2006; 27(1):1014.

[34]. Savery, J. R., Duffy, T. M. Problem based learning: An instructional model and its constructivist framework. Educational technology1995;35(5): 31-38.

How to cite this article:

Sharma M,Bajaj JK, Kaur K, Arora R. INTRODUCTION OF FORMATIVE ASSESSMENT: AN ESSENTIAL COMPONENT OF CBME. Int J Anat Res 2019;7(3.2):6859-6864. DOI: 10.16965/ ijar.2019.242 